\title{
Developing LRP1 Agonists into a Therapeutic Strategy in Acute Myocardial Infarction
}

\author{
Nicola Potere ${ }^{1,2,+}$, Marco Giuseppe Del Buono ${ }^{1,3, \dagger}$, Giampaolo Niccoli $^{3}$, Filippo Crea ${ }^{3}$, \\ Stefano Toldo ${ }^{1}$ and Antonio Abbate ${ }^{1, *}$ \\ 1 VCU Pauley Heart Center, Virginia Commonwealth University, Richmond, VA 23298, USA; \\ nic.potere@gmail.com (N.P.); marcodelbuono@hotmail.it (M.G.D.B.); stefano.toldo@vcuhealth.org (S.T.) \\ 2 Unit of Cardiovascular Sciences, Department of Medicine, Campus Bio-Medico University of Rome, \\ 00128 Rome, Italy \\ 3 Department of Cardiovascular and Thoracic Sciences, Fondazione Policlinico Universitario A. Gemelli, \\ IRCCS, Università Cattolica del Sacro Cuore, 00168 Rome, Italy; gniccoli73@hotmail.it (G.N.); \\ filippo.crea@unicatt.it (F.C.) \\ * Correspondence: antonio.abbate@vcuhealth.org \\ + These authors contributed equally to this paper.
}

Received: 7 December 2018; Accepted: 25 January 2019; Published: 28 January 2019

\begin{abstract}
Cardioprotection refers to a strategy aimed at enhancing survival pathways in the injured yet salvageable myocardium following ischemia-reperfusion. Low-density lipoprotein receptor-related protein 1 (LRP1) is a multifunctional receptor that can be targeted following reperfusion, to induce a cardioprotective signaling through the activation of the reperfusion injury salvage kinase (RISK) pathway. The data from preclinical studies with non-selective and selective LRP1 agonists are promising, showing a large therapeutic window for intervention to reduce infarct size after ischemia-reperfusion. A pilot clinical trial with plasma derived $\alpha 1$-antitrypsin (AAT), a naturally occurring LRP1 agonist, supports the translational value of LRP1 as a novel therapeutic target for cardioprotection. A phase I study with a selective LRP1 agonist has been completed showing no toxicity. These findings may open the way to early phase clinical studies with pharmacologic LRP1 activation in patients with acute myocardial infarction (AMI).
\end{abstract}

Keywords: cardioprotection; ischemia-reperfusion injury; RISK pathway; LRP1

\section{Introduction}

Acute myocardial infarction (AMI) is a leading cause of morbidity and mortality world-wide [1]. The primary cause of AMI is atherothrombosis of a coronary artery plaque following an abrupt plaque destabilizitation [1]. Obstruction of the flow by atherothrombosis leads to acute myocardial ischemia and subsequent cardiomyocyte necrosis [1]. Prompt reperfusion, using either antithrombotic therapies and/or percutaneous coronary intervention, is the most effective strategy to reduce myocardial ischemic injury and improve clinical outcomes in patients with AMI [2]. Despite the timely and effective current myocardial reperfusion strategies, and the ensuing reduction in infarct size, reperfusion is unable to completely halt the progression of the injury wave $[3,4]$. Ischemia-reperfusion injury (IRI) refers to the phenomenon by which the injured yet still viable myocardium, which is in a delicate death-survival balance, is injured by the re-establishment of blood flow and the re-oxygenation of the ischemic myocardium, which is therefore only incompletely salvaged by reperfusion [4]. This secondary wave of injury that occurs despite reperfusion, is a significant contributor to the size of the infarct [4-6]. Hence, experimental strategies aimed at limiting IRI in AMI are expected to reduce the infarct size by at least an additional $25 \%$, aiding in the prevention of left ventricular adverse remodeling and heart failure [4-8]. 
Programmed cell death plays a central role in determining the fate of the injured-yet-salvageable myocardium [9-11]. Concomitant and competing signaling are activated in the myocardium after reperfusion, promoting cell death on the one hand, and cell survival on the other [10]. The stimuli that regulate one versus the opposing pathways are incompletely characterized.

We herein describe the potential role of low-density lipoprotein receptor-related protein 1 (LRP1) signaling, and its modulation in the regulation of cell survival pathways and reduction of IRI.

\section{Pathophysiology of Ischemia-Reperfusion Injury (IRI)}

Ischemic necrosis is preventable and/or minimized by reperfusion. However, reperfusion itself paradoxically accelerates a series of events that result in cellular injury and death [3-5]. Several mechanisms are implicated in the pathogenesis of IRI, including abnormalities in energy production and utilization, alterations of sub-cellular architecture, and different forms of regulated cell death (i.e., necrosis, apoptosis, and pyroptosis) $[5,9,12,13]$.

Reperfusion may exacerbate the damage induced by ischemia through further enhancement of necrotic cell death [14]. Necrosis, initially considered an accidental and unregulated modality of cell death, has recently emerged as a form programmed cell death [14,15]. The mitochondria have indeed emerged as important regulators of both apoptotic and regulated necrotic cell death. The extensive production of reactive oxygen species (ROS), the high intramitochondrial $\mathrm{Ca}^{2+}$ phosphate levels, and adenosine nucleotide depletion create the optimal conditions for a prolonged mitochondrial permeability transition pore ( $\mathrm{mPTP}$ ) opening through the matrix protein cyclophilin $\mathrm{D}(\mathrm{CypD})$, leading to an energetic collapse and irreversible cell damage and death [14,15].

Apoptosis is a finely regulated form of programmed, non-inflammatory, cell death, triggered by reperfusion and due to the rapid restoration of the mitochondrial activity, $\mathrm{pH}$ imbalance, and adenine nucleotides synthesis and release, following a period of prolonged ischemia [9]. The opening of $\mathrm{mPTP}$ and mitochondrial swelling and rupture also lead to the release of pro-apoptogenic mediators, such as cytochrome c, second mitochondria-derived activator of caspase/direct inhibitor of apoptosis-binding protein with low $\mathrm{pI}$ (Smac/DIABLO), Omi/HtrA2, apoptosis-inducing factor (AIF), and endonuclease $G$ (EndoG), from the mitochondrial intermembrane space, promoting caspase- 3 activation and resulting in cardiomyocyte apoptosis [9]. Differently from the necrotic process, caspase activation is an ATP-dependent process requiring some degree of mitochondrial function [15].

Pyroptosis is a form of inflammatory programmed cell death, morphologically and functionally different from apoptosis, and mediated by caspase-1 [6]. Caspase-1 is not part of the canonical apoptotic pathway, and it is activated during pyroptosis by a large supramolecular protein complex, termed inflammasome, which has been widely described as the culprit for the production and secretion of the powerful pro-inflammatory cytokines interleukin-1 $\beta$ (IL-1 $\beta$ ) and interleukin-18 (IL-18) [16]. The most widely characterized inflammasome sensors in the heart are NACHT, LRR, and PYD domains-containing protein 3 (NLRP3), which, during AMI, are activated in response to the cellular debris released by injured tissue in the form of intracellular and extracellular, structurally different molecules, collectively known as damage associated molecular patterns (DAMPs) [6,8]. NLRP3 inflammasome expression and activity are enhanced after one to three hours after reperfusion $[8,17]$. However, NLRP3 also displays signaling functions independent from the inflammasome, which may also have a role in IRI [18].

Numerous studies have been performed to determine the nature of the key death and survival pathways following myocardial ischemia and reperfusion, and several attempts to improve the outcome of reperfusion strategies have followed [5,19]. Identifying the key pathophysiologic mechanisms of IRI may indeed lead to a smaller infarct size and reduced early and long-term mortality in patients with AMI [4,5]. Despite the numerous efforts in understanding the pathophysiology of this process and the encouraging preclinical studies with promising agents [5,19], there are still no cardioprotective strategies approved to limit IRI in clinical practice [7]. The delicate balance between death and survival pathways has been shown to be extremely time-sensitive, limiting the 
opportunities to intervene [19]. However, because of the complexity of the pathophysiology of IRI, targeting exclusively one of the mechanisms implicated in IRI (i.e., necrosis, apoptosis, or pyroptosis) may not be sufficient to completely prevent IRI.

\section{The Reperfusion Injury Salvage Kinase (RISK) Pathway}

The RISK pathway refers to a complex signaling cascade that combines two main pro-survival pathways, the phosphatidylinositol-4,5-bisphosphate 3-kinase (PI3K) and PI3K-protein kinase B (Akt), together with the mitogen-activated protein kinase kinase (MEK) and extracellular signal-regulated kinase 1/2 (ERK1/2) [10,20,21].

The evidence supporting the key role for the RISK pathway derives from the cardioprotective effects observed with pharmacological agents such as urocortin, which are abolished by the co-administration of PI3K-Akt and MEK-ERK1/2 inhibitors [21]. Several pharmacological (i.e., insulin-like growth factor- 1 , transforming growth factor- $\beta 1$, cardiotrophin-1, atorvastatin, and bradykinin) and non-pharmacological (i.e., ischemic pre- and post-conditioning) interventions were similarly shown to stimulate the RISK pathway, to confer cardioprotection upon reperfusion [22]. Therefore, the RISK pathway is nowadays considered the prevailing signaling cascade in cardioprotection following IRI [22].

Recent studies have explored the molecular mechanisms downstream of PI3K-Akt and the ERK1/2, and their interplay to mediate cardioprotection at reperfusion [23]. In brief, the activation of the Akt and/or ERK1/2 kinase cascades results in (1) the indirect inhibition of apoptosis, by the deactivation of key pro-apoptotic proteins thus preventing cytochrome $\mathrm{c}$ release from the mitochondria [24-26]; (2) the inhibition of MPTP opening (leading to abolition of mitochondrial functions and myocyte necrosis) and the activation of the endothelial nitric oxide synthase (eNOS) $[27,28] ;$; 3 the phosphorylation of factors involved in the regulation of gene expression [29-31]; (4) and the direct inhibition of apoptosis, by inactivating caspase-3 and $-9[32,33]$.

The PI3K-Akt signal transduction cascade is mediated by class IA PI3K. PI3K p $110 \alpha$ is coupled to the p101 adaptor protein that is conventionally activated by growth factors through G-protein-coupled receptors (GPCR), participating in the regulation of cell survival, growth, and metabolism [10]. There are several isoforms of PI3K that differ in their preferential expression in different cell types; different locations within the cellular compartments; pairing with different receptors; and phosphorylating a diverse array of substrates, including glycogen synthase kinase-3 (glycogen and protein metabolism), apoptotic proteins (Bad, Bax, Bim, p53 and caspase), GLUT4 vescicles (glucose metabolism), transcription factors (IKK- $\alpha$ and Forkhead proteins), p70S6K, eNOS, and protein kinase c (PKC) [10]. The PI3K produces phosphatidylinositol (3,4,5)-trisphosphate (PIP3), which recruits cytosolic Akt to the plasma membrane, which is then phosphorylated on $\operatorname{Thr}(308)$ by the pyruvate dehydrogenase kinase 1 (PDK1) and on Ser(473) by the mammalian target of rapamycin (mTORC) [10]. Upon full activation, Akt interacts with over 70 known downstream molecular targets [10].

Similarly, the MEK-ERK1/2 pathway (also known as p42/44 MAP kinase pathway) is conventionally activated by tyrosine kinase receptors, G-protein-coupled receptors, and environmental stimuli, and controls cell proliferation, differentiation, and survival [34-36]. The cascade involves the activation of the MEK1/2 by c-Raf, which activates ERK1/2, which, in turn, directly phosphorylates over 160 targets [34-36].

Both Akt and ERK promote mTORC1 signaling, a crucial pathway in cell growth, proliferation, and metabolism, through phosphorylation on the distinct sites of a repressor of mTORC1 activity, a GTPase activator protein, named tuberous sclerosis complex 2 (TSC2) [37]. These events lead to a greater repression of its activity, resulting in a synergic and more powerful stimulation of mTORC1 signaling [37].

The endogenous activation of the RISK pathway during the early reperfusion phase following ischemia limits reperfusion injury. Therefore, the pharmacological stimulation of the RISK pathway represents a therapeutic strategy to reduce reperfusion-mediated cardiomyocyte death. The activation 
of the PI3K and ERK1/2 kinase cascades appears to constitute a universal pro-survival kinase cascade that mediates cardioprotection at reperfusion [10,22].

Necrosis, apoptosis, and pyroptosis are distinct forms of regulated cell death that, however, are not completely independent from each other [15]. Outer mitochondrial membrane rupture following mPTP opening leads to the cytoplasmic release of proteins, such as cytochrome c, from the intermembrane space, activating the apoptotic pathways $[9,15]$. The activation of the inflammasome, along with subsequent caspase- 1 and pyroptosis, leads to the release of the cardio-depressant cytokines IL-1 $\beta$ and IL-18 in the paracrine milieu, and regulates cell death [6]. Furthermore, in some instances, it has been shown that a key inflammasome component, the apoptosis-associated speck-like protein containing a caspase activation and recruitment domain (CARD) (ASC), which is necessary to activate caspase-1 downstream of NLRP3 activation, can engage with caspase-8, thus powering the molecular cross-talk between apoptosis and pyroptosis $[6,38]$. Additionally, the pharmacological inhibition of the NLRP3 inflammasome complex has been reported to be associated with the activation of the RISK pathway (i.e., ERK/Akt/GSK-3 $\beta$ signaling) and with the increase in the expression of mitochondrial oxidative phosphorylation markers [17]. This effect may significantly contribute to the cardioprotective effects associated with NLRP3 inhibition, suggesting a converging role of the NLRP3 inflammasome in the modulation of the apoptotic process [16]. In addition, mitochondrial ROS and oxidized adenosine nucleotide generation, promoted by the opening of $\mathrm{MPTP}$, have been suggested to act as a mitochondrial danger signal, promoting the activation of NLRP3 inflammasome [39]. Therefore, NLRP3 inhibition has emerged as a therapeutic strategy to further reduce the infarct size by limiting, together with pyroptosis and necrosis, the deleterious consequences of apoptosis in the setting of IRI.

Nowadays, several approaches have been described to increase the activity of the component of the RISK pathway and to reduce the cell death. For the purpose of this review, we will focus on a potential novel modulator of the IRI, LRP1 [40].

\section{The Low-Density Lipoprotein (Ldl)-Receptor Related-Protein 1}

LRP1, also known as $\alpha 2$-macroglobulin receptor (A2MR) or cluster of differentiation 91 (CD91), is an ubiquitous multifunctional membrane receptor of the LDL receptor family, mostly known for its role in lipoprotein scavenging [40-45]. Once primarily considered for its role in receptor-mediated endocytosis, it has become clear that LRP1 takes part in multiple signaling pathways involved in protease degradation, glucose homeostasis, modulation of inflammation, coagulation, cell growth, cell survival, and migration [46-49]. LRP1 has been shown to be involved in several disease processes, such as atherosclerosis, cancer, neurodegenerative, and kidney diseases, as well as, recently, in cardiomyocyte protection during IRI $[47,50,51]$.

Three important properties of LRP1 dictate its diverse role in biology, namely: (1) as a scavenger receptor, LRP1 binds and internalizes a variety of ligands for degradation in lysosomes and recycling through its extracellular domain, such as apolipoprotein E and A2MG; (2) as a signaling receptor, it interacts with numerous adaptor proteins through its cytoplasmic domain in a phosphorylation-specific manner and transduces multiple intracellular signals involved in numerous biological processes, as well as regulates nuclear signaling through the small fragment-LRP1 C-terminal intracellular domain (LRP1-ICD) generated by $\gamma$-secretases, and then translocated from the cytoplasm to nucleus; and (3) as a scaffold receptor, it modulates the activity of other membrane proteins such as integrins and receptor tyrosine kinases $[40,47,52,53]$. These singular properties empower LRP1 to couple to an extracellular microenvironment and an intracellular signaling and response [47].

LRP1 is a type 1 transmembrane protein encoded by the Lrp1 gene located on chromosome 12q13-14 [40]. LRP1 derives from a 600-kDa precursor cleaved by furin-like endoproteases in the trans-Golgi complex to form the mature two-chain structure localized in caveolae, namely: a heavy $515-\mathrm{kDa} \alpha$-chain coupled through noncovalent interactions to the light $85-\mathrm{kDa} \beta$-chain, consisting of a transmembrane segment and a cytoplasmic tail $[40,54]$. The extracellular $\alpha$-chain contains four clusters of complement-like repeats, primarily responsible for the ligand-binding activity of LRP1, and 
epidermal growth factor (EGF) repeats [39]. The light $\beta$-chain, which constitutes the transmembrane and the cytosolic domains, includes the tetra amino acidic motif $Y x x L$ and dileucine motifs, serving as principal endocytosis signals; two NPxY motifs, functioning as secondary endocytosis signals and binding sites for signaling adapter proteins; and numerous tyrosine residues, whose phosphorylation is essential for LRP1-mediated signal transduction $[40,44,45,55,56]$.

The LRP1 receptor interacts with over 40 distinct molecules, including several plasma proteases [40,45]. Also known as the SERPIN-enzyme complex (SEC) receptor, LRP1 has the ability to recognize the complex of serine proteinase inhibitors (SERPINs) and serine proteases for subsequent endocytosis and degradation $[40,57,58]$. The binding of the protease-inhibitor complexes to LRP1 is seen across the entire spectrum of SERPINs, such as $\alpha 1$-antitripsin (AAT), A2MG, and antithrombin III $\left(\mathrm{AT}_{\mathrm{III}}\right)$. Certain ligands (e.g., SERPINs, tissue-type plasminogen activator -tPA-) function as LRP1 agonists and stimulate LRP1 direct signaling or transactivate signal pathways through LRP1 co-receptors $[40,45]$.

\subsection{LRP1 and the Modulation of Cell Survival Pathways}

Several in vitro and in vivo studies have shown that LRP1 signaling is crucial in inhibiting death pathways and promoting cell survival [51,59-76] (Table 1).

Table 1. Lipoprotein receptor-related protein 1 (LRP1)-mediated pro-survival signaling pathways.

\begin{tabular}{|c|c|c|c|c|}
\hline Signaling Pathway(s) & Ligand(s) & Co-Receptor(s) & Function & Ref. \\
\hline $\begin{array}{l}\uparrow \mathrm{MAPK} / \mathrm{ERK} \text { and } \\
\text { PI3K-Akt, Src }\end{array}$ & PDGF & PDGFR- $\beta$ & $\begin{array}{l}\text { Regulation of cell migration, } \\
\text { promotion of proliferation } \\
\text { and survival }\end{array}$ & {$[59,60]$} \\
\hline $\begin{array}{c}\uparrow \text { ERK1/2, SFK, PI3K-Akt, } \\
\text { PSD-95 }\end{array}$ & tPA or $\alpha 2 \mathrm{M}$ & Trk, NMDA & Promotion of cell survival & [61-65] \\
\hline 个 ERK1/2, PI3K & MMP-9 & - & $\begin{array}{l}\text { Regulation of cell migration } \\
\text { and promotion of cell survival }\end{array}$ & [66] \\
\hline $\begin{array}{c}\uparrow \text { PI3-Akt } \\
\downarrow \text { caspase-3, NF-kB, } \\
\text { MAPKs }\end{array}$ & IVIg & - & Promotion of cell survival & [67] \\
\hline $\begin{array}{c}\downarrow \text { PI3-Akt } \\
\uparrow \text { caspase-3, NF-kB, } \\
\text { MAPKs }\end{array}$ & $\begin{array}{c}\text { RAP, } \\
\text { LRP1-antibody, } \\
\text { miR-205, siRNA }\end{array}$ & - & $\begin{array}{l}\text { Inhibition of LRP1 promotes } \\
\text { cell death }\end{array}$ & {$[51,77,78]$} \\
\hline
\end{tabular}

Abbreviations: MAPK-mitogen-activated protein kinases; SKF-Src family kinase; ERK-extracellular signal-regulated kinase; PI3K-phosphatidylinositol-4,5-bisphosphate 3-kinase; Akt-PI3K-protein kinase B; NF-kB - nuclear-factor kappa B; PDGF - platelet-derived growth factor; MMP-9 - matrix metalloproteinase-9; IVIg—intravenous immunoglobulin; RAP—receptor associated protein. Upwards arrows $(\uparrow)$ : upregulated signaling pathway(s); downwards arrows $(\downarrow)$ : downregulated signaling pathway(s).

LRP1 expression is necessary for the platelet-derived growth factor (PDGF)-mediated activation of the ERK1/2 protein kinase. LRP1 associates with the PDGF receptor- $\beta$ (PDGFR- $\beta$ ) in the endosomal compartments to modulate its signaling activity on the mitogen-activated protein kinases of the (MAPK)/ERK and PI3K-Akt pathways [59]. The LRP1 cytoplasmic tail is rapidly tyrosine phosphorylated by the PDGF receptor in a src- and PI3K-dependent manner to initiate downstream signaling [60]. Binding of tPA or A2MG to LRP1 in neurons resulted in Src family kinase (SFK) activation and SFK-dependent Trk receptor transactivation, and the subsequent Akt phosphorylation [61]. In neurons, LRP1 induced the phosphorylation of the Ser473 of Akt and reduced apoptosis [62]. The distal NPxY motif in the C terminus of LRP1 was also reported to bridge the N-methyl-D-aspartate (NMDA) receptor through the adaptor protein postsynaptic density protein 95 (PSD95), and initiated tPA-induced ERK1/2 signaling [63-65]. Structurally diverse LRP1 agonists, the LRP1-receptor binding domain of A2MG, and hemopexin domain of matrix metalloproteinase 9 (MMP-9), significantly activated and sustained ERK1/2, and enhanced survival in cultured embryonic sensory neurons [66]. In ischemic neurons, the LRP1 antagonism with receptor associated protein (RAP) dramatically reduced the activation of the Akt survival pathway and the levels of the anti-apoptotic factor Bcl-2, while increasing the activation of caspase-3, nuclear-factor 
kappa B (NF-kB), and MAPKs [67]. Treatment with intravenous immunoglobulin (IVIg), which was previously reported to protect against ischemic stroke-induced brain damage $[79,80]$, reduced these effects in cultured neurons subjected to oxygen-glucose deprivation (OGD) and reperfusion, and significantly increased LRP1 activation in the ischemic hemisphere at $24 \mathrm{~h}$, following middle cerebral artery occlusion (MCAO) and reperfusion [67].

In peripheral nerve injury, LRP1 interacted with various ligands, such as tPA, A2MG, and MMP9, to promote Schwann cells (SCs) survival through Akt and ERK1/2 signal pathways [68-70]. The binding of tPA and MMP-9 to LRP1 induced c-Jun phosphorylation and ERK1/2 activation, with the response being inhibited by the LRP1 antagonist RAP, both in cultured rat and human SCs [71]. Intriguingly, c-Jun phosphorylation is a central event in the activation of the SCs repair program, supporting a model whereby LRP1 may also serve as an injury detection receptor in the peripheral nerve system [71]. The silencing of LRP1 with small interfering siRNA decreased phosphorylated Akt and increased activated caspase-3 in SCs, and comparable changes in the cell signaling were observed in LRP1 deficient murine embryonic fibroblasts [68]. Likewise, SC-specific LRP1 deletion exacerbated nerve injury, confirming the pro-survival effect of LRP1 signaling [72].

In macrophages, LRP1 deficiency increased apoptotic cell death and inflammation by impairing Akt activation [73]. LRP1 mediated tPA-induced M1 macrophage survival through a pathway involving ERK1/2, p90RSK, and p38 MAPK [74]. The LRP1 inhibition abrogated the lactoferrin-induced ERK1/2 signaling in primary rat osteoblastic cells [75]. Furthermore, the PDGF-mediated phosphorylation also resulted in an increased association of the adaptor protein Shc with LRP1, and the increased c-Jun $\mathrm{N}$-terminal kinase (JNK) association at the plasma membrane prevented JNK translocation to the nucleus and gene regulation, thus inhibiting JNK signaling [76]. The JNK pathway, one of the major signaling cassettes of the MAPK signaling pathway, promotes apoptosis [81].

Thus, LRP1 appears to serve as a common receptor of multiple ligands to mediate their cytoprotective effects by activating different pro-survival signaling cascades. However, the specific contribution of LRP1 in the regulation of other cell death processes, such as necrosis and pyroptosis, has not been studied, and, therefore, whether LRP1 signaling also affects these phenomena is currently unknown.

\subsection{Role of LRP1 in Inflammatory Signaling}

LRP1 signaling also modulates the inflammatory response. LRP1 ligands increase in injured tissues and accelerate the resolution of the inflammatory response [46]. In macrophages, LRP1 was reported to play an essential role in mediating tPA anti-inflammatory cell signaling and the down-regulation of the expression of several cytokines [82]. Other LRP1 ligands, such as A2MG and MMP9, have a similar anti-inflammatory activity [47,69]. After ligand binding, the cytoplasmic fragment of LRP1 undergoes proteolysis by $\gamma$-secretases [83] and migrates to the nucleus, where it binds to the interferon regulatory factor-3 (IRF-3) and promotes its nuclear export and proteasomal degradation, thus limiting the expression of the pro-inflammatory genes in cultured fibroblasts and macrophages [84]. The LRP1-agonist complex was also found to inhibit the interleukin-1 receptor associated kinase-1 (IRAK-1), leading to the down-regulation of the NF-kB pro-inflammatory signaling pathway in vascular smooth muscle cells (VSMCs) [85].

LRP1 regulates the signaling of various membrane proteins, including the cell surface calreticulin $(\mathrm{CRT})$ and the transforming growth factor- $\beta$ (TGF- $\beta$ ) receptor. LRP1 acts as a signaling co-receptor for CRT and mediates the effects of the matricellular soluble protein thrombospondin 1 (TSP1), which regulates cell adhesion and migration [86]. LRP1 signaling also appeared to facilitate TGF- $\beta$ activity and promoted fibroblast expansion and maturation, leading to increased collagen deposition and scar, whereas the disruption of the LRP1 signaling appeared to impair this same process. This experimental evidence may be independent of LRP1 signaling, and may rather be through a scaffold function of LRP1 on the cell membrane [87]. 
Altogether, these experimental evidences allow one to speculate that LRP1 represents a key mechanism inhibiting cell death, and promoting the resolution of the inflammation and the formation of a scar following tissue injury [88]. These functions make LRP1 a molecular target of interest in the setting of acute myocardial ischemia and infarction.

\subsection{Role of LRP1 in Acute Myocardial Ischemia and Infarction}

LRP1 expression is markedly enhanced during hypoxemia and/or ischemia $[51,89,90]$ under the regulation of the hypoxia-inducible factor- $1 \alpha$ (HIF-1 $\alpha)$ in cardiomyocytes, as well as in cardiac fibroblasts [89-92] (Figure 1).
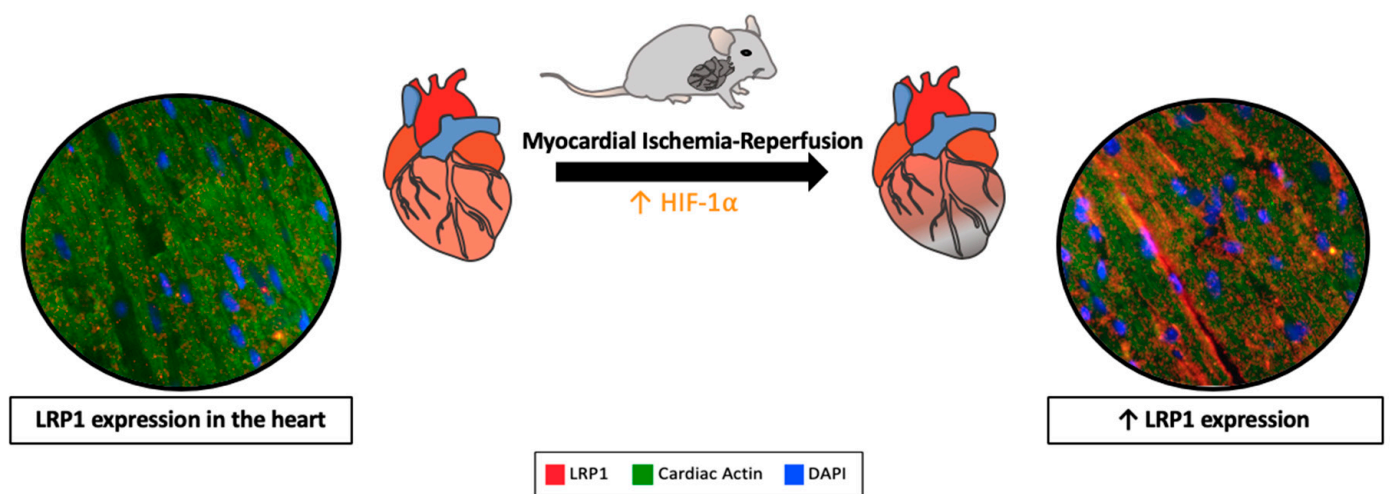

Figure 1. Lipoprotein receptor-related protein 1 (LRP1) expression is increased in the myocardial tissue after ischemia-reperfusion. Hypoxia upregulates LRP1 expression through induction of the hypoxia-inducible factor- $1 \alpha(\mathrm{HIF}-1 \alpha)$ in cardiomyocytes.

LRP1 was also strongly up-regulated in the myocardial tissue in the animal models of ischemia-reperfusion $[51,90,91]$, as well as in patients with ischemic cardiomyopathy, supporting a role for LRP1 in IRI [51]. However, the specific role of LRP1 as a scavenger/signaling/scaffold receptor in cardiomyocytes has not been investigated until recently [51,90,92,93].

Multiple gain- and loss-of-function studies indicated that LRP1 protects against cardiomyocyte death and dysfunction through its ability to promote Akt- and ERK1/2-dependent survival pathways $[51,77,78]$ (Table 2), consistent with what is described in neurons, Schwann cells, macrophages, fibroblasts, and osteoblasts [52-69,79,80].

Table 2. LRP1-mediated signaling in acute myocardial ischemia and infarction.

\begin{tabular}{|c|c|c|c|c|}
\hline $\begin{array}{l}\text { Signaling } \\
\text { Pathway(s) }\end{array}$ & LRP1 Ligand(s) & Effect/Function & $\begin{array}{c}\text { Cell Types/Experimental } \\
\text { Model }\end{array}$ & References \\
\hline $\begin{array}{l}\uparrow \text { PI3K-Atk and } \\
\text { MEK1/2-ERK1/2 }\end{array}$ & A2MG & $\begin{array}{l}\uparrow \text { Protein synthesis and cell } \\
\text { growth }\end{array}$ & $\begin{array}{l}\text { Rat ventricular } \\
\text { cardiomyocytes }\end{array}$ & [77] \\
\hline 个 PI3k-Akt & Adiponectin & $\begin{array}{c}\downarrow \text { Apoptosis and } \uparrow \text { cell } \\
\text { survival }\end{array}$ & Cardiomyocytes & [78] \\
\hline $\begin{array}{l}\downarrow \text { pPyk } 2 / \uparrow \text { HIF- } 1 \alpha / \downarrow \\
\text { SERCA2 }\end{array}$ & VLDL, CE & Contractile dysfunction & Cardiomyocytes & [93] \\
\hline$\uparrow \mathrm{pPyk} 2 / \uparrow$ MMP-9 & - & Fibrosis & Cardiac fibroblasts & [92] \\
\hline$\uparrow$ Cathepsin secretion & $\mathrm{CE}$ & $\begin{array}{c}\uparrow \text { CatS secretion and altered } \\
\text { secreted TE (altered } \\
\text { extracellular matrix) }\end{array}$ & Cardiomyocytes & [94] \\
\hline 个 PI3K-Atk & $\begin{array}{c}\text { Plasma derived AAT, } \\
\text { Recombinant AAT, } \\
\text { AT }_{\text {III }} \text {, Plasma derived } \\
\text { A2MG, SP16 }\end{array}$ & $\begin{array}{c}\downarrow \text { Apoptosis, } \downarrow \text { infarct size, } \uparrow \\
\text { systolic function }\end{array}$ & $\begin{array}{c}\text { Myocardial } \\
\text { ischemia-reperfusion } \\
\text { model }\end{array}$ & [51,95-99] \\
\hline
\end{tabular}

Abbreviations: CatS—cathepsin S; TE—tropoelastin; HIF-1 1 -hypoxia-inducible factor- $1 \alpha$; AAT— $\alpha 1$-antitrypsin; CE—cholesteryl ester; A2MG— $\alpha 2$-macroglobulin; VLDL—very low-density lipoprotein. Upwards arrows $(\uparrow)$ : upregulated signaling pathway(s); downwards arrows $(\downarrow)$ : downregulated signaling pathway(s). 
LRP1 initiates the PI3K-Akt and MEK1/2-ERK1/2 signaling cascades shortly after the incubation of rat ventricular cardiomyocytes with A2MG, and induces protein synthesis and cell growth [77]. Treatment with a LRP1 stimulating antibody either in the presence or absence of A2MG resulted in comparable effects, while co-incubation with receptor associated protein (RAP), which sequesters LRP1 preventing ligand binding, significantly counteracted this hypertrophic response [77]. The effects elicited by A2MG-LRP1 signaling were abolished by the pre-treatment of cardiomyocytes with the MEK inhibitor UO126, the PI3K inhibitors LY294002 and wortmannin, and rapamycin, which inhibits mTOR downstream of Akt [77].

Ohashi et al. have previously shown that adiponectin through LRP1 and CRT promotes the neovascularization of ischemic muscle through a cyclooxygenase 2(COX-2)-dependent mechanism in endothelial cells [100]. It was later shown that the LRP1/CRT co-receptor system stimulates Akt phosphorylation and inhibits doxorubicin-induced apoptosis, whereas siRNA or blocking antibodies against LRP1 diminished the stimulatory effects of adiponectin on Akt activation and cardiomyocyte survival [78]. Although the specific involvement of LRP1 in the different death mechanisms (i.e., necrosis, apoptosis, and pyroptosis) needs to be further investigated, altogether, these data show that LRP1 signaling results in a protective effect in cardiomyocytes.

LRP1 has also been reported to be involved in cardiomyocyte lipid metabolism and calcium handling under ischemic conditions [90,91,93] (Table 2). Hypoxia-induced LRP1 expression led to an increased LRP1 scavenging function associated with an increased very low-density lipoprotein-cholesteryl ester (VLDL-CE) internalization. On the other hand, the deletion of LRP1 through lentiviral-mediated interfering RNA reduced the hypoxia-induced VLDL-CE uptake in HL-1 cardiomyocytes [90]. CE accumulated in the infarct area and in the bordering myocardium together with LRP1 up-regulation in a porcine model of ischemia-reperfusion [91]. This was speculated to be an attempt to reduce the oxidation of extracellular lipids through LRP1's scavenging function, and/or a source of energy for the ischemic heart. Other investigators have proposed that cardiomyocytes exposed to hypoxic conditions in vitro become dysfunctional because of excessive lipid endocytosis, although this remains controversial [93]. In 2015, the Llorente-Cortés group observed that hypoxia-induced LRP1 up-regulation was concomitantly associated with reduced phosphorylation of the $\mathrm{Ca}^{2+-}$ dependent non-receptor tyrosine kinase proline-rich tyrosine kinase 2 (Pyk2), which in turn overloads the nucleus with the NF-kB and HIF- $1 \alpha$ transcription factors, repressing sarcoplasmic reticulum $\mathrm{Ca}^{2+}$ ATPase (SERCA2) transcription and activity in HL-1 cardiomyocytes [93]. The modulation of the LRP1/pPyk2/HIF- $1 \alpha$ axis may be useful to mitigate hypoxia-induced SERCA2 depletion, one of the main alterations in contractile dysfunction after AMI [93]. Notably, despite its negative effects on SERCA2 levels under hypoxic conditions, the proposed role for HIF- $1 \alpha$ is protective in acute cardiac ischemia [101]. This may be due to the fact that, while ischemia occurs rapidly, hypoxia develops over a longer period of time.

Furthermore, various studies have highlighted the role of LRP1 in cardiac remodeling after AMI $[92,94]$. Enhanced LRP1-mediated cardiomyocyte intracellular CE accumulation up-regulated cathepsin S (CatS), a cysteine protease with the ability to degrade extracellular matrix (ECM) components, and altered structural and physical characteristics of secreted tropoelastin (TE), one of the main components of ECM [94]. LRP1 expression and protein levels markedly increased in the cardiac fibroblasts of the peri-infarct area at 10 and 21 days following permanent coronary artery ligation. The ERK1/2 expression and phosphorylation were strongly up-regulated in the infarct areas at 1,10 , and 21 days, while the pPky2 expression peaked in the infarct and peri-infarct areas at 10 and 21 days after AMI. The LRP1/pPyk2 axis up-regulated MMP-9 in cardiac fibroblasts, suggesting that LRP1 modulates the fibrotic response that follows the ischemic injury [92]. Taken together, these data allow one to speculate that LRP1 mediates the distinct spatial and temporal activation of ERK1/2and Pyk2-dependent pathways in cardiomyocytes and fibroblasts, and may explain the differential contribution of these two signaling pathways in the immediate and later phases after AMI [92]. 


\subsection{Effects of LRP1 Agonists in Ischemia Reperfusion}

The binding of SERPINs to LRP1 was shown to induce a pro-survival signal in several experimental settings, though its effects in a myocardial ischemia-reperfusion model remained unexplained until recently. LRP1 non-selective stimulation by SERPINs, such as with plasma-derived AAT, A2MG, and $\mathrm{AT}_{\text {III, }}$ or with recombinant human AAT, significantly limited IRI [95-99]. Plasma derived AAT considerably inhibited cardiomyocyte death in vitro and in vivo [95], and the effects persisted when a clinically relevant scenario, such as prolonged ischemia (up to $75 \mathrm{~min}$ ), delayed the administration of the drug (up to $30 \mathrm{~min}$ ), and a large therapeutic index, was modeled in mice [96]. The use of different isoforms of recombinant fusion proteins composed of human AAT and FC portion of IgGs, showed that the protective effects of AAT are independent from the inhibition of elastase activity [99]. Furthermore, it was also shown that treatment with LRP1 blocking antibody eliminated the benefits of AAT, suggesting that the cardioprotective effect of AAT is mediated by LRP1 signaling [51]. $\mathrm{AT}_{\text {III }}$ reduced the infarct size in mice, independent of its anticoagulant activity [98]. Plasma derived A2MG provided a similar cardioprotective signal across a large dose range in a mouse model of ischemia-reperfusion [97]. Collectively, these data demonstrate that distinct non-selective SERPINs that act as LRP1 agonists limited the IRI in mice (Figure 2). Based on these data, it has been recently proposed that selectively enhancing LRP1 signaling with a targeted agonist would have a comparable cardioprotective effect [51].

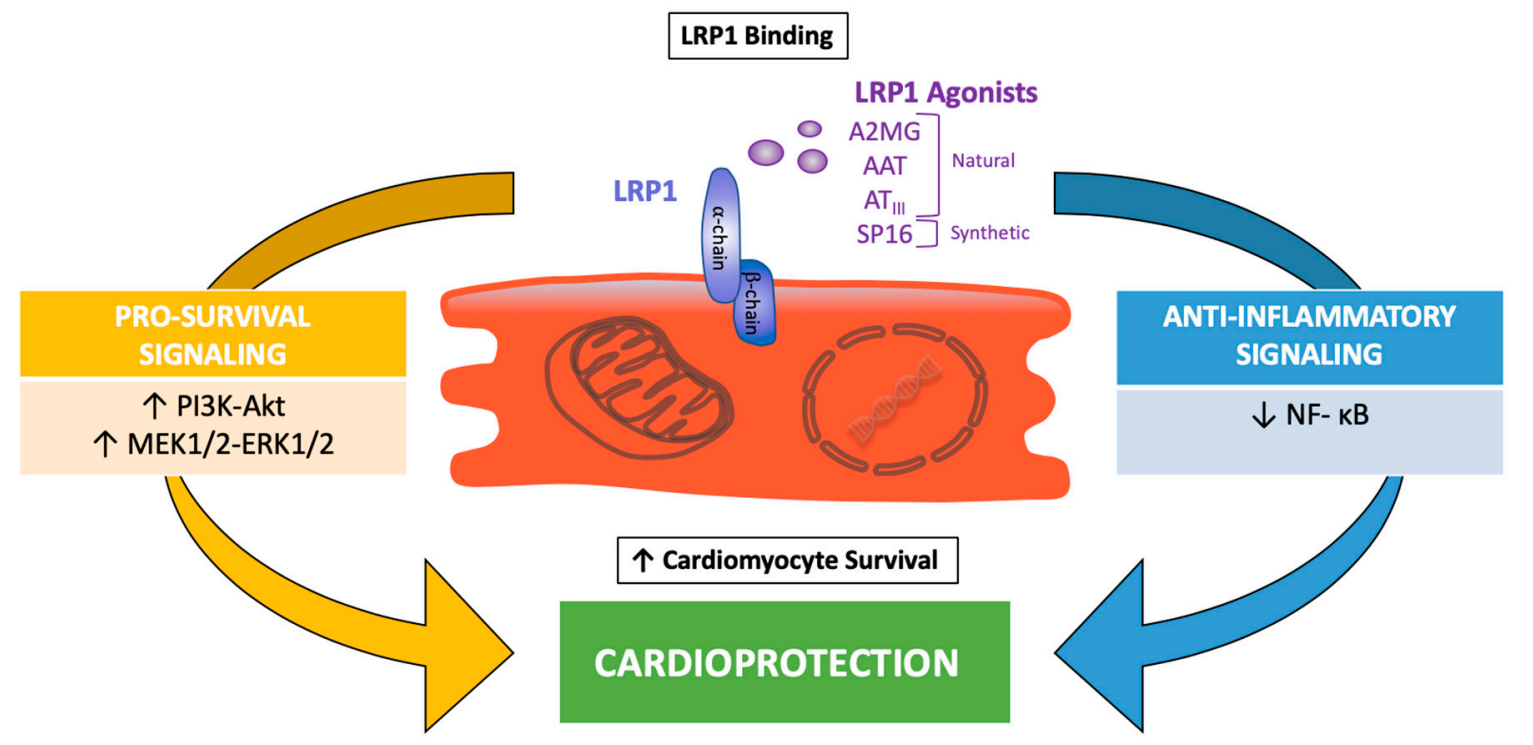

Figure 2. LRP1 protective signaling in myocardial ischemia reperfusion. Binding of natural serine proteinase inhibitors (SERPINs; $\alpha 2$-macroglobulin (A2MG), $\alpha 1$-antitrypsin (AAT), and antithrombin III $\left(\mathrm{AT}_{\mathrm{III}}\right)$ ) and synthetic LRP1 agonists (SP16) induces cytoprotective signals in cardiomyocytes through the activation of pro-survival and anti-inflammatory signaling pathways.

The short peptide LRP1 agonist, SP16, administered in mice intraperitoneally after reperfusion, significantly reduced the infarct size and preserved the left ventricular systolic function in a dose-dependent fashion [51]. The cardioprotective effects were maintained when SP16 was given subcutaneously at reperfusion or 30 minutes after reperfusion, whereas pre-treatment with the LRP1 blocking antibody abolished the benefits of SP16, confirming that a functional LRP1 receptor is indispensable to induce cardioprotection during experimental AMI [51]. Similarly, the inducible deletion of cardiac LRP1 using a Cre-lox system eliminates the infarct-sparing effects of SP16, confirming the specific role of cardiomyocyte LRP1 signaling in protecting the heart from acute ischemia [personal communication by the authors]. LRP1 stimulation through SP16 induced a rapid phosphorylation of the Akt protein kinase, associated with a reduction in proapoptotic 
to the antiapoptotic Bax/Bcl2 ratio and caspase-3 activity, in the heart tissue at $24 \mathrm{~h}$ from ischemia-reperfusion [51]. These findings support the concept that the upregulation of the RISK pathway mediates the protective effects of LRP1 in IRI (Figure 2).

Following IRI, the inflammatory response is necessary to promote infarct healing, but at the same time, the activation of key pro-inflammatory pathways induces a further loss of viable myocardium, leading to adverse ventricular remodeling and heart failure after AMI. Besides its pro-survival activity, LRP1 agonism has also proven to quench inflammatory signals. In vitro, the LRP1 agonist SP16 inhibited NLRP3 inflammasome activation and down-regulated NF- $\kappa B$ signaling following lipopolysaccharide (LPS) and Gp96 stimulation in a leukocyte assay, and treatment with the LRP1 blocking antibody dissipated these anti-inflammatory effects [51]. This is consistent with the significant reduction in infarct scar size and leukocyte infiltration in the peri-infarct border zone observed seven days from ischemia-reperfusion [51].

\subsection{Clinical Experience with LRP1 Agonists in Ami}

Promising pre-clinical studies with cyclosporine and other mitochondrial membrane permeability inhibitors failed to translate from bench to bedside, possibly as a result of inconsistent efficacy, doseand time-dependent limitations, and concomitant standard-of-care treatment with $\mathrm{P}_{2} \mathrm{Y}_{12}$ receptor antagonists, which have been shown to independently provide, at least in part, some cardioprotective effects $[19,102,103]$. The data on LRP1 signaling and use of agonists show a much longer therapeutic window (up to two hours after reperfusion in the mouse), which would allow for treatment in time to provide a reduction in IRI.

Clinical data with plasma derived AAT, which functions as a non-selective LRP1 agonist, in patients with ST segment elevation acute myocardial infarction (STEMI), are limited to a pilot clinical feasibility trial (VCU- $\alpha 1$ RT pilot study, clinicaltrials.gov, NCT01936896) [104]. A single intravenous administration of $60 \mathrm{mg} / \mathrm{kg}$ AAT within 12 hours from admission showed a favorable safety profile, and, when compared to a historical placebo-treated group from a parallel clinical trial, the plasma derived AAT was associated with a blunted acute inflammatory response as indicated by lower C reactive protein (CRP) levels [104] and reduced estimated infarct size, measured as the area under the curve for creatine kinase-myocardial band (CK-MB) [105]. There were no treatment-related serious adverse events. Of note, none of the patients treated with AAT had incident HF after one year, compared with one patient who died and nine patients who experienced heart failure $(50 \%)$ in the placebo comparison group [105].

Selective LRP1 agonists are under clinical development. A phase I clinical trial testing with SP16 in healthy volunteers has been completed showing no toxicity(clinicaltrials.gov, NCT03651089) [106].

\subsection{Controversies in the Field of Cardioprotection and Translational Outlook}

The research field of cardioprotection has for decades been searching for a suitable strategy that could minimize, or prevent, lethal IRI after AMI. Despite many encouraging pre-clinical studies, which identified interventions that dramatically lower the infarct size, these studies have not translated into a clinically applicable drug or intervention in patients with AMI [2,5,7]. This gap between animal and clinical studies may have different explanations, including species differences; use of young and healthy animal models; poor experimental design; dose- and time-dependent limitations; and insufficient pre-clinical testing, including a lack of blinding by an independent validation by different laboratories $[7,19,107]$. For instance, the introduction of $\mathrm{P}^{2} \mathrm{Y}_{12}$ receptor antagonists as adjuvant antiplatelet therapy for all patients with AMI, has been proposed by some authors as a major factor for this lack of success in translating cardioprotective strategies into clinical settings [102,103]. $\mathrm{P}_{2} \mathrm{Y}_{12}$ receptor antagonists have potent anti-platelet effects and proposed cardioprotective effects, not attributable to the inhibition of platelet aggregation, through the modulation of signaling involving the RISK pathway [102,103]. Hence, it has been suggested that P2Y 12 antagonists have already maximally 
triggered the RISK pathway, and other therapeutic interventions targeting the same pathway would give little additional benefit [102].

Future pre-clinical investigations would therefore need to further explore the cardioprotective molecular mechanisms of LRP1 modulation independently of the RISK pathway, including inducible cardiomyocyte-, endothelial-, leukocyte-, and fibroblast-restricted LRP1 deletion, in order to evaluate the cell-specific contribution of LRP1 stimulation during AMI, as well as testing in combination with a $\mathrm{P}_{2} \mathrm{Y}_{12}$ receptor antagonist in order to determine whether the new experimental approach would produce a synergic, more powerful, cardioprotective effect. It is worth noting, however, that in the pilot clinical trial with the LRP1 agonist, AAT, all of the patients had been pre-treated with a P2Y 12 receptor antagonist, yet a benefit for the LRP1 agonist appeared to be maintained [104,105].

\section{Conclusions}

LRP1 is a multifunctional receptor that can be targeted following reperfusion to induce a cardioprotective signaling through the RISK pathway. The data from preclinical studies with non-selective and selective LRP1 agonists are promising, showing a large therapeutic window for intervention to reduce infarct size after ischemia reperfusion. A pilot clinical trial with plasma derived AAT, a naturally occurring LRP1 agonist, supports the potential translational value of LRP1 as a novel therapeutic target for cardioprotection. A phase I study with a selective LRP1 agonist has been completed showing no toxicity. These findings may open the way to early phase clinical studies with pharmacologic LRP1 activation in patients with AMI.

Author Contributions: N.P., M.G.D.B., G.N., F.C., S.T., and A.A. have made substantial, direct, and intellectual contributions to the work and approved it for publication. N.P. and M.G.D.B. wrote the initial draft of the manuscript. N.P. and M.G.D.B. created the initial draft of the figures and tables. A.A., S.T., G.N., and F.C. critically revised the whole manuscript. Conceptualization, A.A., S.T., N.P., and M.G.D.B.; methodology, A.A., S.T., N.P., and M.G.D.B.; software, $\mathrm{n} / \mathrm{a}$; validation, $\mathrm{n} / \mathrm{a}$; formal analysis, $\mathrm{n} / \mathrm{a}$; investigation, $\mathrm{n} / \mathrm{a}$; resources, $\mathrm{n} / \mathrm{a}$; data curation, n/a; writing (original draft preparation), N.P. and M.G.D.B.; writing (review and editing), A.A., S.T., G.N., and F.C.; visualization, $\mathrm{n} / \mathrm{a}$; supervision, A.A. and S.T.; project administration, $\mathrm{n} / \mathrm{a}$; funding acquisition, $\mathrm{n} / \mathrm{a}$, please turn to the CRediT taxonomy for the term explanation.

Funding: This research received no external funding. Dr. Abbate is supported by the National Heart, Lung, and Blood Institute (Bethesda, MA, USA), grant (R56 HL136816).

Conflicts of Interest: Antonio Abbate has served as a consultant to Serpin Pharma (Manassas, VA, USA).

$\begin{array}{ll}\text { Abbreviations } \\ \text { AIF } & \text { Apoptosis-inducing factor } \\ \text { IL-1 } \beta & \text { Interleukin-1 } \beta \\ \text { IL-18 } & \text { Interleukin-18 } \\ \text { NLRP3 } & \text { NACHT, LRR, and PYD domains-containing protein 3 } \\ \text { DAMPs } & \text { Damage associated molecular patterns } \\ \text { PI3K } & \text { phosphatidylinositol-4,5-bisphosphate 3-kinase } \\ \text { Akt } & \text { PI3K-protein kinase B } \\ \text { MEK } & \text { mitogen-activated protein kinase kinase } \\ \text { ERK } & \text { Extracellular signal-regulated kinase } \\ \text { eNOS } & \text { Endothelial nitric oxide synthase } \\ \text { GPCR } & \text { G-protein-coupled receptors } \\ \text { PDK1 } & \text { Pyruvate dehydrogenase kinase 1 } \\ \text { mTORC } & \text { Mammalian target of rapamycin } \\ \text { TSC2 } & \text { Tuberous sclerosis complex 2 } \\ \text { ASC } & \text { Apoptosis-associated Speck-like protein containing a CARD } \\ \text { CD91 } & \text { Cluster of differentiation 91 } \\ \text { EGF } & \text { Epidermal growth factor } \\ \text { SEC } & \text { SERPIN-enzyme complex } \\ \text { SERPINs } & \text { Serine proteinase inhibitors } \\ \text { A2MG } & \alpha 2-m a c r o g l o b u l i n \\ & \end{array}$




\begin{tabular}{ll}
$\alpha 2 M R$ & $\alpha 2$-macroglobulin receptor \\
AT & Antithrombin III \\
tPA & Tissue-type plasminogen activator \\
PDGF & Platelet-derived growth factor \\
PDGFR- $\beta$ & PDGF receptor- $\beta$ \\
SFK & Src family kinase \\
NMDA & N-methyl-D-aspartate \\
PSD95 & Postsynaptic density protein 95 \\
MMP-9 & Matrix metalloproteinase-9 \\
RAP & Receptor associated protein \\
NF-kB & Nuclear-factor kappa B \\
MAPKs & Mitogen-activated protein kinases \\
IVIg & Intravenous immunoglobulin \\
MCAO & Middle cerebral artery occlusion \\
SCs & Schwann cells \\
siRNA & Short interference RNA \\
JNK & c-Jun N-terminal kinase \\
IRF-3 & Interferon regulatory factor-3 \\
IRAK-1 & Interleukin-1 receptor associated kinase-1 \\
VSMCs & Vascular smooth muscle cells \\
CRT & Calreticulin \\
TGF- $\beta$ & Transforming growth factor- $\beta$ \\
TSP1 & Thrombospondin 1 \\
HIF-1 $\alpha$ & Hypoxia-inducible factor-1 $\alpha$ \\
COX-2 & Cyclooxygenase 2 \\
VLDL & Very low-density lipoprotein \\
CE & Cholesteryl ester \\
Pyk2 & Proline-rich tyrosine kinase 2 \\
SERCA2 & Sarcoplasmic reticulum Ca ${ }^{2+}$ ATPase \\
CatS & Cathepsin S \\
TE & Tropoelastin \\
LPS & Lipopolysaccharide \\
STEMI & ST segment elevation acute myocardial infarction \\
CRP & C reactive protein \\
IRI & Ischemia-reperfusion injury \\
LRP1 & Low-density lipoprotein receptor-related protein 1 \\
RISK & Reperfusion injury salvage kinase \\
AMI & Acute myocardial infarction \\
mPTP & Mitochondrial permeability transition pore \\
AAT & $\alpha 1$-antitrypsin \\
ROS & \\
& \\
& Reactive oxygen species \\
\hline
\end{tabular}

\section{References}

1. Thygesen, K.; Alpert, J.S.; Jaffe, A.S.; Chaitman, B.R.; Bax, J.J.; Morrow, D.A.; White, H.D.; ESC Scientific Document Group. Fourth universal definition of myocardial infarction (2018). Eur. Heart J. 2018. [CrossRef] [PubMed]

2. Ibáñez, B.; Heusch, G.; Ovize, M.; Van de Werf, F. Evolving Therapies for Myocardial Ischemia/Reperfusion Injury. J. Am. Coll. Cardiol. 2015, 65, 1454-1471. [CrossRef] [PubMed]

3. Braunwald, E.; Kloner, R.A. Myocardial reperfusion: A double-edged sword? J. Clin. Invest. 1985, 76, 13-19. [CrossRef] [PubMed]

4. Yellon, D.M.; Hausenloy, D.J. Myocardial Reperfusion Injury. N. Engl. J. Med. 2007, 357, 1121-1135. [CrossRef]

5. Hausenloy, D.J.; Yellon, D.M. Myocardial ischemia-reperfusion injury: A neglected therapeutic target. J. Clin. Investig. 2013, 123, 92-100. [CrossRef]

6. Toldo, S.; Mauro, A.G.; Cutter, Z.S.; Abbate, A. Inflammasome, pyroptosis, and cytokines in myocardial ischemia-reperfusion injury. Am. J. Physiol. Circ. Physiol. 2018. [CrossRef]

7. Hausenloy, D.J.; Garcia-Dorado, D.; Bøtker, H.E.; Davidson, S.M.; Downey, J.; Engel, F.B.; Jennings, R.; Lecour, S.; Leor, J.; Madonna, R.; et al. Novel targets and future strategies for acute cardioprotection: Position Paper of the European Society of Cardiology Working Group on Cellular Biology of the Heart. Cardiovasc. Res. 2017, 113, 564-585. [CrossRef] [PubMed] 
8. Toldo, S.; Abbate, A. The NLRP3 inflammasome in acute myocardial infarction. Nat. Rev. Cardiol. 2017, 15, 203-214. [CrossRef]

9. Eefting, F.; Rensing, B.; Wigman, J.; Pannekoek, W.J.; Liu, W.M.; Cramer, M.J.; Lips, D.J.; Doevendans, P.A. Role of apoptosis in reperfusion injury. Cardiovasc. Res. 2004, 61, 414-426. [CrossRef]

10. Hausenloy, D.; Yellon, D.M. New directions for protecting the heart against ischaemia-reperfusion injury: Targeting the Reperfusion Injury Salvage Kinase (RISK)-pathway. Cardiovasc. Res. 2004, 61, 448-460. [CrossRef]

11. Turer, A.T.; Hill, J.A. Pathogenesis of Myocardial Ischemia-Reperfusion Injury and Rationale for Therapy. Am. J. Cardiol. 2010, 106, 360-368. [CrossRef] [PubMed]

12. Heusch, G.; Gersh, B.J. The pathophysiology of acute myocardial infarction and strategies of protection beyond reperfusion: A continual challenge. Eur. Heart J. 2016, 38, 774-784. [CrossRef] [PubMed]

13. Hausenloy, D.J.; Chilian, W.; Crea, F.; Davidson, S.M.; Ferdinandy, P.; Garcia-Dorado, D.; van Royen, N.; Schulz, R.; Heusch, G. The coronary circulation in acute myocardial ischaemia/reperfusion injury-A target for cardioprotection. Cardiovasc. Res. 2018. [CrossRef] [PubMed]

14. Linkermann, A.; Bräsen, J.H.; Darding, M.; Jin, M.K.; Sanz, A.B.; Heller, J.O.; De Zen, F.; Weinlich, R.; Ortiz, A.; Walczak, H.; et al. Two independent pathways of regulated necrosis mediate ischemia-reperfusion injury. Proc. Natl. Acad. Sci. USA 2013, 110, 12024-12029. [CrossRef] [PubMed]

15. Karch, J.; Molkentin, J.D. Regulated necrotic cell death: The passive aggressive side of Bax and Bak. Circ. Res. 2015. [CrossRef]

16. Miao, E.A.; Rajan, J.V.; Aderem, A. Caspase-1-induced pyroptotic cell death. Immunol. Rev. 2011, 243, 206-214. [CrossRef] [PubMed]

17. Toldo, S.; Marchetti, C.; Mauro, A.G.; Chojnacki, J.; Mezzaroma, E.; Carbone, S.; Zhang, S.; Van Tassell, B.; Salloum, F.N.; Abbate, A. Inhibition of the NLRP3 inflammasome limits the inflammatory injury following myocardial ischemia-reperfusion in the mouse. Int. J. Cardiol. 2016, 209, 215-220. [CrossRef] [PubMed]

18. Mastrocola, R.; Penna, C.; Tullio, F.; Femminò, S.; Nigro, D.; Chiazza, F.; Serpe, L.; Collotta, D.; Alloatti, G.; Cocco, M.; et al. Pharmacological Inhibition of NLRP3 Inflammasome Attenuates Myocardial Ischemia/Reperfusion Injury by Activation of RISK and Mitochondrial Pathways. Oxid. Med. Cell. Longev. 2016. [CrossRef]

19. Trankle, C.; Thurber, C.J.; Toldo, S.; Abbate, A. Mitochondrial Membrane Permeability Inhibitors in Acute Myocardial Infarction: Still Awaiting Translation. JACC Basic Transl. Sci. 2016, 1, 524-535. [CrossRef]

20. Schulman, D.; Latchman, D.S.; Yellon, D.M. Urocortin protects the heart from reperfusion injury via upregulation of p42/p44 MAPK signaling pathway. Am. J. Physiol. Hear. Circ. Physiol. 2002, 283, 1481-1488. [CrossRef]

21. Hausenloy, D.J.; Tsang, A.; Mocanu, M.M.; Yellon, D.M. Ischemic preconditioning protects by activating prosurvival kinases at reperfusion. Am. J. Physiol. Circ. Physiol. 2005, 288, H971-H976. [CrossRef] [PubMed]

22. Hausenloy, D.J.; Yellon, D.M. Reperfusion injury salvage kinase signalling: Taking a RISK for cardioprotection. Heart Fail Rev. 2007, 12, 217-234. [CrossRef] [PubMed]

23. Haunsenloy, D.J.; Mocanu, M.M.; Yellon, D.M. Cross-talk between the survival kinases during early reperfusion: Its contribution to ischemic preconditioning. Cardiovasc. Res. 2004, 63, 305-312. [CrossRef] [PubMed]

24. Harada, H.; Andersen, J.S.; Mann, M.; Terada, N.; Korsmeyer, S.J. p70S6 kinase signals cell survival as well as growth, inactivating the pro-apoptotic molecule BAD. Proc. Natl. Acad. Sci. USA 2008, 98, 9666-9670. [CrossRef] [PubMed]

25. Tsuruta, F.; Masuyama, N.; Gotoh, Y. The Phosphatidylinositol 3-Kinase (PI3K)-Akt Pathway Suppresses Bax Translocation to Mitochondria. J. Biol. Chem. 2002, 277, 14040-14047. [CrossRef] [PubMed]

26. Weston, C.R.; Balmanno, K.; Chalmers, C.; Hadfield, K.; Molton, S.A.; Ley, R.; Wagner, E.F.; Cook, S.J. Activation of ERK1/2 by $\triangle$ Raf-1: ER* represses Bim expression independently of the JNK or PI3K pathways. Oncogene 2003, 22, 1281-1293. [CrossRef]

27. Balakirev, M.Y.; Khramtsov, V.V.; Zimmer, G. Modulation of the mitochondrial permeability transition by nitric oxide. Eur. J. Biochem. 1997, 246, 710-718. [CrossRef]

28. Dimmeler, S.; Fleming, I.; Fisslthaler, B.; Hermann, C.; Busse, R.; Zeihe, A.M. Activation of nitric oxide synthase in endothelial cells by Akt-dependent phosphorylation. Nature 1999, 399, 601-605. [CrossRef] 
29. Romashkova, J.A.; Makarov, S.S. NF- $\mathrm{B}$ is a target of AKT in anti-apoptotic PDGF signalling. Nature 1999, 401, 86-90. [CrossRef]

30. Brunet, A.; Bonni, A.; Zigmond, M.J.; Lin, M.Z.; Juo, P.; Hu, L.S.; Anderson, M.J.; Arden, K.C.; Blenis, J.; Greenberg, M.E. Akt promotes cell survival by phosphorylating and inhibiting a Forkhead transcription factor. Cell 1999, 96, 857-868. [CrossRef]

31. Bonni, A.; Brunet, A.; West, A.E.; Datta, S.R.; Takasu, M.A.; Greenberg, M.E. Cell survival promoted by the Ras-MAPK signaling pathway by transcription-dependent and -independent mechanisms. Science 1999, 286, 1358-1362. [CrossRef] [PubMed]

32. Terada, K.; Kaziro, Y.; Satoh, T. Analysis of Ras-Dependent Signals That Prevent Caspase-3 Activation and Apoptosis Induced by Cytokine Deprivation in Hematopoietic Cells. Biochem. Biophys. Res. Commun. 2000, 167, 449-455. [CrossRef] [PubMed]

33. Cardone, M.H.; Roy, N.; Stennicke, H.R.; Salvesen, G.S.; Franke, T.F.; Stanbridge, E.; Frisch, S.; Reed, J.C. Regulation of cell death protease caspase-9 by phosphorylation. Science 1998, 282, 1318-1321. [CrossRef]

34. Widmann, C.; Gibson, S.; Jarpe, M.B.; Johnson, G.L. Mitogen-Activated Protein Kinase: Conservation of a Three-Kinase Module From Yeast to Human. Physiol. Rev. 1999, 79, 143-180. [CrossRef] [PubMed]

35. Shimizu, N.; Yoshiyama, M.; Omura, T.; Hanatani, A.; Kim, S.; Takeuchi, K.; Iwao, H.; Yoshikawa, J. Activation of mitogen-activated protein kinases and activator protein-1 in myocardial infarction in rats. Cardiovasc. Res. 1998, 38, 116-124. [CrossRef]

36. Yue, T.L.; Wang, C.; Gu, J.L.; Ma, X.L.; Kumar, S.; Lee, J.C.; Feuerstein, G.Z.; Thomas, H.; Maleeff, B.; Ohlstein, E.H. Inhibition of extracellular signal-regulated kinase enhances Ischemia/Reoxygenation-induced apoptosis in cultured cardiac myocytes and exaggerates reperfusion injury in isolated perfused heart. Circ. Res. 2000, 86, 692-699. [CrossRef]

37. Winter, J.N.; Jefferson, L.S.; Kimball, S.R. ERK and Akt signaling pathways function through parallel mechanisms to promote mTORC1 signaling. Am. J. Physiol. Physiol. 2011, 300, C1172-C1180. [CrossRef] [PubMed]

38. Vince, J.E.; Silke, J. The intersection of cell death and inflammasome activation. Cell. Mol. Life Sci. 2016, 73, 2349-2367. [CrossRef] [PubMed]

39. Shimada, K.; Crother, T.R.; Karlin, J.; Dagvadorj, J.; Chiba, N.; Chen, S.; Ramanujan, V.K.; Wolf, A.J.; Vergnes, L.; Ojcius, D.M.; et al. Oxidized mitochondrial DNA activates the NLRP3 inflammasome during apoptosis. Immunity 2012. [CrossRef]

40. Lillis, A.P.; Van Duyn, L.B.; Murphy-Ullrich, J.E.; Strickland, D.K. LDL Receptor-Related Protein 1: Unique Tissue-Specific Functions Revealed by Selective Gene Knockout Studies. Physiol. Rev. 2008, 88, 887-918. [CrossRef]

41. Herz, J.; Hamann, U.; Rogne, S.; Myklebost, O.; Gausepohl, H.; Stanley, K.K. Surface location and high affinity for calcium of a 500-kd liver membrane protein closely related to the LDL-receptor suggest a physiological role as lipoprotein receptor. EMBO J. 1988, 7, 4119-4127. [CrossRef] [PubMed]

42. Strickland, D.; Ashcom, J.D.; Williams, S.; Burgess, W.H.; Migliorini, M.; Argraves, W.S. Sequence Identity between the alpha 2- Macroglobulin Receptor and Low Density Lipoprotein Receptor-related Protein Suggests That This Molecule Is a Multifunctional. J. Biol. Chem. 1990, 265, 17401-17404.

43. Kristensen, T.; Moestrup, S.K.; Gliemann, J.; Bendtsen, L.; Sand, O.; Sottrup-Jensen, L. Evidence that the newly cloned low-density-lipoprotein receptor related protein (LRP) is the $\alpha 2$-macroglobulin receptor. FEBS Lett. 1990, 276, 151-155. [CrossRef]

44. Hussain, M.M. Structural, biochemical and signaling properties of the low-density lipoprotein receptor gene family. Front. Biosci. 2001, 6, D417-D428. [PubMed]

45. Herz, J.; Strickland, D.K. LRP: A multifunctional scavenger and signaling receptor. J. Clin. Invest. 2001, 108, 779-784. [CrossRef] [PubMed]

46. Lillis, A.P.; Mikhailenko, I.; Strickland, D.K. Beyond endocytosis: LRP function in cell migration, proliferation and vascular permeability. J. Thromb. Haemost. 2005, 3, 1884-1893. [CrossRef] [PubMed]

47. Gonias, S.L.; Campana, W.M. LDL receptor-related protein-1: A regulator of inflammation in atherosclerosis, cancer, and injury to the nervous system. Am. J. Pathol. 2014, 184, 18-27. [CrossRef]

48. Franchini, M.; Montagnana, M. Low-density lipoprotein receptor-related protein 1: New functions for an old molecule. Clin. Chem. Lab. Med. 2011, 49, 967-970. [CrossRef] 
49. Dato, V.A.; Chiabrando, G.A. The role of low-density lipoprotein receptor-related protein 1 in lipid metabolism, glucose homeostasis and inflammation. Int. J. Mol. Sci. 2018, 19, 1-13.

50. Lin, L.; Hu, K. LRP-1: Functions, signaling and implications in kidney and other diseases. Int. J. Mol. Sci. 2014, 15, 22887-22901. [CrossRef]

51. Toldo, S.; Austin, D.; Mauro, A.G.; Mezzaroma, E.; Van Tassell, B.W.; Marchetti, C.; Carbone, S.; Mogelsvang, S.; Gelber, C.; Abbate, A. Low-Density Lipoprotein Receptor-Related Protein-1 Is a Therapeutic Target in Acute Myocardial Infarction. JACC Basic Transl. Sci. 2017, 2, 561-574. [CrossRef]

52. Strickland, D.K.; Ranganathan, S. Diverse role of LDL receptor-related protein in the clearance of proteases and in signaling. J. Thromb. Haemost. 2003, 1, 1663-1670. [CrossRef] [PubMed]

53. Mao, H.; Xie, L.; Pi, X. Low-Density Lipoprotein Receptor-Related Protein-1 Signaling in Angiogenesis. Front. Cardiovasc. Med. 2017, 4, 34. [CrossRef] [PubMed]

54. Herz, J.; Kowal, R.C.; Goldstein, J.L.; Brown, M.S. Proteolytic processing of the $600 \mathrm{kd}$ low density lipoprotein receptor-related protein (LRP) occurs in a trans-Golgi compartment. EMBO J. 1990, 9, 1769-1776. [CrossRef] [PubMed]

55. Trommsdorff, M.; Gotthardt, M.; Hiesberger, T.; Shelton, J.; Stockinger, W.; Nimpf, J.; Hammer, R.E.; Richardson, J.A.; Herz, J. Reeler/Disabled-like disruption of neuronal migration in knockout mice lacking the VLDL receptor and ApoE receptor 2. Cell 1999, 97, 689-701. [CrossRef]

56. Barnes, H.; Larsen, B.; Tyers, M.; van der Geer, P. Tyrosine-phosphorylated Low Density Lipoprotein Receptor-related Protein 1 (LRP1) Associates with the Adaptor Protein SHC in SRC-transformed Cells. J. Biol. Chem. 2001, 276, 19119-19125. [CrossRef] [PubMed]

57. Perlmutter, D.H.; Glover, G.I.; Rivetna, M.; Schasteen, C.S.; Fallon, R.J. Identification of a serpin-enzyme complex receptor on human hepatoma cells and human monocytes. Proc. Natl. Acad. Sci. USA 1990, 87, 3753-3757. [CrossRef]

58. Silverman, G.A.; Bird, P.I.; Carrell, R.W.; Church, F.C.; Coughlin, P.B.; Gettins, P.G.; Irving, J.A.; Lomas, D.A.; Luke, C.J.; Moyer, R.W.; et al. The serpins are an expanding superfamily of structurally similar but functionally diverse proteins. Evolution, mechanism of inhibition, novel functions, and a revised nomenclature. J. Biol. Chem. 2001, 276, 33293-33296. [CrossRef] [PubMed]

59. Muratoglu, S.C.; Mikhailenko, I.; Newton, C.; Migliorini, M.; Strickland, D.K. Low density lipoprotein receptor-related protein 1 (LRP1) forms a signaling complex with platelet-derived growth factor receptor-beta in endosomes and regulates activation of the MAPK pathway. J. Biol. Chem. 2010, 285, 14308-14317. [CrossRef]

60. Loukinova, E.; Ranganathan, S.; Kuznetsov, S.; Gorlatova, N.; Migliorini, M.M.; Loukinov, D.; Ulery, P.G.; Mikhailenko, I.; Lawrence, D.A.; Strickland, D.K. Platelet-derived growth factor (PDGF)-induced tyrosine phosphorylation of the low density lipoprotein receptor-related protein (LRP). Evidence for integrated co-receptor function between LRP and the PDGF. J. Biol. Chem. 2002, 277, 15499-15506. [CrossRef] [PubMed]

61. Shi, Y.; Mantuano, E.; Inoue, G.; Campana, W.M.; Gonias, S.L. Ligand Binding to LRP1 Transactivates Trk Receptors by a Src Family Kinase-Dependent Pathway. Sci. Signal. 2009, 2, ra18. [CrossRef] [PubMed]

62. Fuentealba, R.A.; Liu, Q.; Kanekiyo, T.; Zhang, J.; Bu, G. Low Density Lipoprotein Receptor-related Protein 1 Promotes Anti-apoptotic Signaling in Neurons by Activating Akt Survival Pathway. J. Biol. Chem. 2009, 284, 34045-34053. [CrossRef] [PubMed]

63. May, P.; Rohlmann, A.; Bock, H.H.; Zurhove, K.; Marth, J.D.; Schomburg, E.D.; Noebels, J.L.; Beffert, U.; Sweatt, J.D.; Weeber, E.J.; et al. Neuronal LRP1 Functionally Associates with Postsynaptic Proteins and Is Required for Normal Motor Function in Mice. Mol. Cell. Biol. 2004, 24, 8872-8883. [CrossRef] [PubMed]

64. Martin, A.M.; Kuhlmann, C.; Trossbach, S.; Jaeger, S.; Waldron, E.; Roebroek, A.; Luhmann, H.J.; Laatsch, A.; Weggen, S.; Lessmann, V.; et al. The functional role of the second NPXY motif of the LRP1 beta-chain in tissue-type plasminogen activator-mediated activation of N-methyl-D-aspartate receptors. J. Biol. Chem. 2008, 283, 12004-12013. [CrossRef] [PubMed]

65. Mantuano, E.; Lam, M.S.; Gonias, S.L. LRP1 Assembles Unique Co-receptor Systems to Initiate Cell Signaling in Response to Tissue-type Plasminogen Activator and Myelin-associated Glycoprotein. J. Biol. Chem. 2013, 288, 34009-34018. [CrossRef] [PubMed]

66. Yamauchi, K.; Yamauchi, T.; Mantuano, E.; Murakami, K.; Henry, K.; Takahashi, K.; Campana, W.M. Low-Density Lipoprotein Receptor Related protein-1 (LRP1)-Dependent Cell Signaling Promotes Neurotrophic Activity in Embryonic Sensory Neurons. PLoS ONE 2013, 8, e75497. [CrossRef] 
67. Lok, K.Z.; Manzanero, S.; Arumugam, T.V. Neuronal low-density lipoprotein receptor-related protein 1 (LRP1) enhances the anti-apoptotic effect of intravenous immunoglobulin (IVIg) in ischemic stroke. Brain Res. 2016, 1644, 192-202. [CrossRef] [PubMed]

68. Campana, W.M.; Li, X.; Dragojlovic, N.; Janes, J.; Gaultier, A.; Gonias, S.L. The low-density lipoprotein receptor-related protein is a pro-survival receptor in Schwann cells: Possible implications in peripheral nerve injury. J. Neurosci. 2006, 26, 11197-11207. [CrossRef]

69. Mantuano, E.; Inoue, G.; Li, X.; Takahashi, K.; Gaultier, A.; Gonias, S.L.; Campana, W.M. The Hemopexin Domain of Matrix Metalloproteinase-9 Activates Cell Signaling and Promotes Migration of Schwann Cells by Binding to Low-Density Lipoprotein Receptor-Related Protein. J. Neurosci. 2008, 28, 11571-11582. [CrossRef]

70. Mantuano, E.; Jo, M.; Gonias, S.L.; Campana, W.M. Low Density Lipoprotein Receptor-related Protein (LRP1) Regulates Rac1 and RhoA Reciprocally to Control Schwann Cell Adhesion and Migration. J. Biol. Chem. 2010, 285, 14259-14266. [CrossRef] [PubMed]

71. Flütsch, A.; Flütsch, A.; Henry, K.; Mantuano, E.; Lam, M.S.; Shibayama, M.; Takahashi, K.; Gonias, S.L.; Campana, W.M. Evidence that LDL receptor-related protein 1 acts as an early injury detection receptor and activates c-Jun in Schwann cells. Neuroreport 2016, 27, 1305-1311. [CrossRef] [PubMed]

72. Orita, S.; Henry, K.; Mantuano, E.; Yamauchi, K.; De Corato, A.; Ishikawa, T.; Feltri, M.L.; Wrabetz, L.; Gaultier, A.; Pollack, M.; et al. Schwann Cell LRP1 Regulates Remak Bundle Ultrastructure and Axonal Interactions to Prevent Neuropathic Pain. J. Neurosci. 2013, 33, 5590-5602. [CrossRef] [PubMed]

73. Yancey, P.G.; Blakemore, J.; Ding, L.; Fan, D.; Overton, C.D.; Zhang, Y.; Linton, M.F.; Fazio, S. Macrophage LRP-1 Controls Plaque Cellularity by Regulating Efferocytosis and Akt Activation. Arterioscler. Thromb. Vasc. Biol. 2010, 30, 787-795. [CrossRef] [PubMed]

74. Lin, L.; Jin, Y.; Hu, K. Tissue-type plasminogen activator (tPA) promotes M1 macrophage survival through p90 ribosomal S6 kinase (RSK) and p38 mitogen-activated protein kinase (MAPK) pathway. J. Biol. Chem. 2015, 290, 7910-7917. [CrossRef] [PubMed]

75. Grey, A.; Banovic, T.; Zhu, Q.; Watson, M.; Callon, K.; Palmano, K.; Ross, J.; Naot, D.; Reid, I.R.; Cornish, J. The Low-Density Lipoprotein Receptor-Related Protein 1 Is a Mitogenic Receptor for Lactoferrin in Osteoblastic Cells. Mol. Endocrinol. 2004, 18, 2268-2278. [CrossRef] [PubMed]

76. Lutz, C.; Nimpf, J.; Jenny, M.; Boecklinger, K.; Enzinger, C.; Utermann, G.; Baier-Bitterlich, G.; Baier, G. Evidence of Functional Modulation of the MEKK/JNK/cJun Signaling Cascade by the Low Density Lipoprotein Receptor-related Protein (LRP). J. Biol. Chem. 2002, 277, 43143-43151. [CrossRef] [PubMed]

77. Padmasekar, M.; Nandigama, R.; Wartenberg, M.; Schlüter, K.-D.; Sauer, H. The acute phase protein alpha2-macroglobulin induces rat ventricular cardiomyocyte hypertrophy via ERK1,2 and PI3-kinase/Akt pathways. Cardiovasc. Res. 2007, 75, 118-128. [CrossRef]

78. Maruyama, S.; Shibata, R.; Ohashi, K.; Ohashi, T.; Daida, H.; Walsh, K.; Murohara, T.; Ouchi, N. Adiponectin Ameliorates Doxorubicin-induced Cardiotoxicity through Akt Protein-dependent Mechanism. J. Biol. Chem. 2011, 286, 32790-32800. [CrossRef]

79. Arumugam, T.V.; Tang, S.C.; Lathia, J.D.; Cheng, A.; Mughal, M.R.; Chigurupati, S.; Magnus, T.; Chan, S.L.; Jo, D.G.; Ouyang, X.; et al. Intravenous immunoglobulin (IVIG) protects the brain against experimental stroke by preventing complement-mediated neuronal cell death. Proc. Natl. Acad. Sci. USA 2007, 104, 14104-14109. [CrossRef]

80. Fann, D.Y.; Lee, S.Y.; Manzanero, S.; Tang, S.C.; Gelderblom, M.; Chunduri, P.; Bernreuther, C.; Glatzel, M.; Cheng, Y.L.; Thundyil, J.; et al. Intravenous immunoglobulin suppresses NLRP1 and NLRP3 inflammasome-mediated neuronal death in ischemic stroke. Cell Death Dis. 2013, 4, e790. [CrossRef]

81. Dhanasekaran, D.N.; Reddy, E.P. JNK signaling in apoptosis. Oncogene 2008, 27, 6245-6251. [CrossRef] [PubMed]

82. Mantuano, E.; Azmoon, P.; Brifault, C.; Banki, M.A.; Gilder, A.S.; Campana, W.M.; Gonias, S.L. Tissue-type plasminogen activator regulates macrophage activation and innate immunity. Blood 2017, 130, 1364-1374. [CrossRef] [PubMed]

83. Derocq, D.; Prébois, C.; Beaujouin, M.; Laurent-Matha, V.; Pattingre, S.; Smith, G.K.; Liaudet-Coopman, E. Cathepsin D is partly endocytosed by the LRP1 receptor and inhibits LRP1-regulated intramembrane proteolysis. Oncogene 2012, 31, 3202-3212. [CrossRef] [PubMed]

84. Zurhove, K.; Nakajima, C.; Herz, J.; Bock, H.H.; May, P. Gamma-Secretase Limits the Inflammatory Response Through the Processing of LRP1. Sci. Signal. 2008, 1, ra15. [CrossRef] [PubMed] 
85. Kawamura, A.; Baitsch, D.; Telgmann, R.; Feuerborn, R.; Weissen-Plenz, G.; Hagedorn, C.; Saku, K.; Brand-Herrmann, S.M.; von Eckardstein, A.; Assmann, G.; et al. Apolipoprotein E Interrupts Interleukin-1 $\beta$ Signaling in Vascular Smooth Muscle Cells. Arterioscler. Thromb. Vasc. Biol. 2007, 27, 1610-1617. [CrossRef]

86. Orr, A.W.; Pedraza, C.E.; Pallero, M.A.; Elzie, C.A.; Goicoechea, S.; Strickland, D.K.; Murphy-Ullrich, J.E. Low density lipoprotein receptor-related protein is a calreticulin coreceptor that signals focal adhesion disassembly. J. Cell Biol. 2003, 161, 1179-1189. [CrossRef]

87. Cabello-Verrugio, C.; Brandan, E. A Novel Modulatory Mechanism of Transforming Growth Factor- $\beta$ Signaling through Decorin and LRP-1. J. Biol. Chem. 2007, 282, 18842-18850. [CrossRef]

88. Wujak, L.; Schnieder, J.; Schaefer, L.; Wygrecka, M. LRP1: A chameleon receptor of lung inflammation and repair. Matrix Biol. 2018, 68-69, 366-381. [CrossRef]

89. Castellano, J.; Aledo, R.; Sendra, J.; Costales, P.; Juan-Babot, O.; Badimon, L.; Llorente-Cortés, V. Hypoxia Stimulates Low-Density Lipoprotein Receptor-Related Protein-1 Expression Through Hypoxia-Inducible Factor- $1 \alpha$ in Human Vascular Smooth Muscle Cells. Arterioscler. Thromb. Vasc. Biol. 2011, 31, 1411-1420. [CrossRef]

90. Cal, R.; Castellano, J.; Revuelta-López, E.; Aledo, R.; Barriga, M.; Farré, J.; Vilahur, G.; Nasarre, L.; Hove-Madsen, L.; Badimon, L.; et al. Low-density lipoprotein receptor-related protein 1 mediates hypoxia-induced very low density lipoprotein-cholesteryl ester uptake and accumulation in cardiomyocytes. Cardiovasc. Res. 2012, 94, 469-479. [CrossRef]

91. Drevinge, C.; Karlsson, L.O.; Ståhlman, M.; Larsson, T.; Perman Sundelin, J.; Grip, L.; Andersson, L.; Borén, J.; Levin, M.C. Cholesteryl esters accumulate in the heart in a porcine model of ischemia and reperfusion. PLoS ONE 2013, 8, e61942. [CrossRef] [PubMed]

92. Revuelta-López, E.; Soler-Botija, C.; Nasarre, L.; Benitez-Amaro, A.; de Gonzalo-Calvo, D.; Bayes-Genis, A.; Llorente-Cortés, V. Relationship among LRP1 expression, Pyk2 phosphorylation and MMP-9 activation in left ventricular remodelling after myocardial infarction. J. Cell. Mol. Med. 2017, 21, 1915-1928. [CrossRef] [PubMed]

93. Revuelta-López, E.; Cal, R.; Herraiz-Martínez, A.; de Gonzalo-Calvo, D.; Nasarre, L.; Roura, S.; Gálvez-Montón, C.; Bayes-Genis, A.; Badimon, L.; Hove-Madsen, L.; et al. Hypoxia-driven sarcoplasmic/endoplasmic reticulum calcium ATPase 2 (SERCA2) downregulation depends on low-density lipoprotein receptor-related protein 1 (LRP1)-signalling in cardiomyocytes. J. Mol. Cell. Cardiol. 2015, 85, 25-36. [CrossRef] [PubMed]

94. Samouillan, V.; Revuelta-López, E.; Dandurand, J.; Nasarre, L.; Badimon, L.; Lacabanne, C.; Llorente-Cortés, V. Cardiomyocyte intracellular cholesteryl ester accumulation promotes tropoelastin physical alteration and degradation: Role of LRP1 and cathepsin S. Int. J. Biochem. Cell Biol. 2014, 55, 209-219. [CrossRef] [PubMed]

95. Toldo, S.; Seropian, I.M.; Mezzaroma, E.; Van Tassell, B.W.; Salloum, F.N.; Lewis, E.C.; Voelkel, N.; Dinarello, C.A.; Abbate, A. Alpha-1 antitrypsin inhibits caspase-1 and protects from acute myocardial ischemia-reperfusion injury. J. Mol. Cell. Cardiol. 2011, 51, 244-251. [CrossRef] [PubMed]

96. Mauro, A.G.; Mezzaroma, E.; Marchetti, C.; Narayan, P.; Del Buono, M.G.; Capuano, M.; Prestamburgo, A.; Catapano, S.; Salloum, F.N.; Abbate, A.; et al. A Preclinical Translational Study of the Cardioprotective Effects of Plasma-Derived Alpha-1 Anti-trypsin in Acute Myocardial Infarction. J. Cardiovasc. Pharmacol. 2017, 69, 273-278. [CrossRef]

97. Toldo, S.; Mauro, A.G.; Narayan, P.; Kundur, P.; La Neve, F.; Mezzaroma, E.; Abbate, A. Plasma Derived Alpha-2 Macroglobulin Limits the Inflammatory Injury in a Mouse Myocardial Ischemia-reperfusion Model. Circulation 2018. [CrossRef]

98. Wang, J.; Wang, Y.; Wang, J.; Gao, J.; Tong, C.; Manithody, C.; Li, J.; Rezaie, A.R. Antithrombin is protective against myocardial ischemia and reperfusion injury. J. Thromb. Haemost. 2013, 11, 1020-1028. [CrossRef]

99. Toldo, S.; Mauro, A.G.; Marchetti, C.; Rose, S.W.; Mezzaroma, E.; Van Tassell, B.W.; Kim, S.; Dinarello, C.A.; Abbate, A. Recombinant Human Alpha-1 Antitrypsin-Fc Fusion Protein Reduces Mouse Myocardial Inflammatory Injury After Ischemia-Reperfusion Independent of Elastase Inhibition. J. Cardiovasc. Pharmacol. 2016, 68, 27-32. [CrossRef]

100. Ohashi, K.; Ouchi, N.; Sato, K.; Higuchi, A.; Ishikawa, T.O.; Herschman, H.R.; Kihara, S.; Walsh, K. Adiponectin promotes revascularization of ischemic muscle through a cyclooxygenase 2-dependent mechanism. Mol. Cell. Biol. 2009, 29, 3487-3499. [CrossRef] 
101. Eckle, T.; Kohler, D.; Lehmann, R.; El Kasmi, K.C.; Eltzschig, H.K. Hypoxia-Inducible Factor-1 Is Central to Cardioprotection. Circulation 2008, 118, 166-175. [CrossRef] [PubMed]

102. Cohen, M.V.; Downey, J.M. The impact of irreproducibility and competing protection from $\mathrm{P}_{2} \mathrm{Y}_{12}$ antagonists on the discovery of cardioprotective interventions. Bas. Res. Card. 2017, 112, 64. [CrossRef]

103. Yang, X.M.; Liu, Y.; Cui, L.; Yang, X.; Liu, Y.; Tandon, N.; Kambayashi, J.; Downey, J.M.; Cohen, M.V. Platelet $\mathrm{P}_{2} \mathrm{Y}_{12}$ blockers confer direct postconditioning-like protection in reperfused rabbit hearts. J. Card. Pharm. Ther. 2013, 18, 251-262. [CrossRef] [PubMed]

104. Abbate, A.; Van Tassell, B.W.; Christopher, S.; Abouzaki, N.A.; Sonnino, C.; Oddi, C.; Carbone, S.; Melchior, R.D.; Gambill, M.L.; Roberts, C.S.; et al. Effects of Prolastin C (Plasma-Derived Alpha-1 Antitrypsin) on the Acute Inflammatory Response in Patients With ST-Segment Elevation Myocardial Infarction (from the VCU-Alpha 1-RT Pilot Study). Am. J. Cardiol. 2015, 115, 8-12. [CrossRef] [PubMed]

105. Abouzaki, N.A.; Christopher, S.; Trankle, C.; Van Tassell, B.W.; Carbone, S.; Mauro, A.G.; Buckley, L.; Toldo, S.; Abbate, A. Inhibiting the Inflammatory Injury After Myocardial Ischemia Reperfusion With Plasma-Derived Alpha-1 Antitrypsin. J. Cardiovasc. Pharmacol. 2018, 71, 375-379. [CrossRef] [PubMed]

106. SP16 SERPIN-like Peptide Administration in Healthy Individuals. Available online: https://clinicaltrials. gov/ct2/show / NCT03651089?term=sp16\&rank=1 (accessed on 27 January 2019).

107. Jones, S.P.; Tang, X.L.; Guo, Y.; Steenbergen, C.; Lefer, D.J.; Kukreja, R.C.; Kong, M.; Li, Q.; Bhushan, S.; $\mathrm{Zhu}, \mathrm{X}$; et al. The NHLBI-sponsored Consortium for preclinicAl assESsment of cARdioprotective therapies (CAESAR): A new paradigm for rigorous, accurate, and reproducible evaluation of putative infarct-sparing interventions in mice, rabbits, and pigs. Circ. Res. 2015, 16, 572-586. [CrossRef] [PubMed]

(C) 2019 by the authors. Licensee MDPI, Basel, Switzerland. This article is an open access article distributed under the terms and conditions of the Creative Commons Attribution (CC BY) license (http:// creativecommons.org/licenses/by/4.0/). 